\title{
X-Ray Photoelectron Spectroscopy of Murataite Ceramics Containing Lanthanides
}

\author{
K. I. Maslakov ${ }^{a}$, Yu. A. Teterin ${ }^{a, b, *}$, O. I. Stefanovskaya ${ }^{c}$, \\ S. N. Kalmykov ${ }^{a, b, c}$, A. Yu. Teterin ${ }^{b}$, K. E. Ivanov ${ }^{b}$, \\ S. S. Danilov ${ }^{d}$, S. V. Yudintsev ${ }^{c, e}$, and B. F. Myasoedov ${ }^{c}$ \\ ${ }^{a}$ Lomonosov Moscow State University, Faculty of Chemistry, Moscow, 119991 Russia \\ ${ }^{b}$ National Research Center "Kurchatov Institute", Moscow, 123182 Russia \\ ${ }^{c}$ Frumkin Institute of Physical Chemistry and Electrochemistry, Russian Academy of Sciences, Moscow, 119071 Russia \\ ${ }^{d}$ Vernadsky Institute of Geochemistry and Analytical Chemistry, Russian Academy of Sciences, Moscow, 119991 Russia \\ ${ }^{e}$ Institute of Geology of Ore Deposits, Petrography, Mineralogy and Geochemistry, Russian Academy of Sciences, \\ Moscow, 119017 Russia \\ *e-mail: yuteterin@yandex.ru
}

Received August 3, 2020; revised August 3, 2020; accepted September 19, 2020

\begin{abstract}
Ceramic samples with the following composition (wt \%): $50 \mathrm{TiO}_{2}, 10 \mathrm{CaO}, 10 \mathrm{MnO}_{2}, 5 \mathrm{Al}_{2} \mathrm{O}_{3}, 5 \mathrm{Fe}_{2} \mathrm{O}_{3}$, $10 \mathrm{ZrO}_{2}, 10 \mathrm{Ln}_{2} \mathrm{O}_{3}(\mathrm{Ln}=\mathrm{La}, \mathrm{Ce}, \mathrm{Nd}, \mathrm{Ho})$ or $10 \mathrm{CeO}_{2}$, were studied by X-ray photoelectron spectroscopy. According to the data of $\mathrm{X}$-ray phase analysis and scanning electron microscopy, they consist of murataite, zirconolite, and perovskite. In smaller quantities there are crichtonite, pyrophanite-ilmenite, and rutile. $\mathrm{Ce}^{3+}$ dominates in cerium samples: the $\mathrm{Ce}^{3+}: \mathrm{Ce}^{4+}$ ratio is $3: 1$ and does not depend on the method of adding the element to the charge-in the form of $\mathrm{CeO}_{2}$ or $\mathrm{Ce}_{2} \mathrm{O}_{3}$. All ceramics are dominated by $\mathrm{Fe}^{3+}$, its fraction is $92-94$ rel \%, while manganese is represented only by $\mathrm{Mn}^{3+}$ cations.
\end{abstract}

Keywords: lanthanides, ceramics, murataite, valency, XPS

DOI: $10.1134 / \mathrm{S} 1066362221060126$

\section{INTRODUCTION}

High-level waste (HLW) from nuclear power and military activities is vitrified for subsequent placement in underground storage facilities [1-5]. Glasses do not fully meet the requirements for waste matrices in terms of safety and economy. Their capacity for waste is rather low, especially that of aluminophosphate glasses $[1,6]$, which reduces the efficiency of using the underground HLW storage. When such matrices come into contact with water, colloidal particles that can migrate in the geological environment are formed. Glasses are metastable formations and will crystallize over time, which will cause an increase in the leaching rate of radionuclides due to the appearance of soluble newly formed phases [7]. In the future, it is planned to employ new technologies for reprocessing spent nuclear fuel (SNF), including the separation of HLW into groups of elements [3]. This fact makes it relevant to search new matrices for the immobilization of actinides, for example, crystalline materials based on titanates and zirconates
[2-5, 8-10]. Such promising matrices of actinides and rare-earth elements (REE) actinides include, in particular $[10,11]$, pyrochlore-based ceramics (double fluorite cell, Py)-muratite (triple fluorite cell, M3) with intermediate members M5 and M8 (murataites with a five- or eight-fold fluorite unit cell). Upon crystallization from the melt, they are formed in the sequence: Py $\rightarrow$ M5 $\rightarrow$ M8 $\rightarrow$ M3 with the formation of zoned grains with a maximum concentration of actinides and rare earths in their central part $[3,11]$.

Light lanthanides of the cerium group ( $\mathrm{La}, \mathrm{Ce}, \mathrm{Nd}$, $\mathrm{Sm}, \mathrm{Pr}$ ) dominate in the REE-actinide fraction and also serve as imitators of actinides in the corresponding oxidation states: $\mathrm{La}^{3+}$ and $\mathrm{Nd}^{3+}$ for $\mathrm{Am}^{3+}$ and $\mathrm{Cm}^{3+}$, $\mathrm{Ce}^{3+/ 4+}$ for $\mathrm{Pu}^{3+/ 4+}$. Therefore, data on the oxidation state of lanthanides in ceramics are of scientific and practical interest. The method of X-ray photoelectron spectroscopy (XPS) makes it possible to determine the elemental and ionic composition of the surface of the samples [12-17]. Previously, this method was 

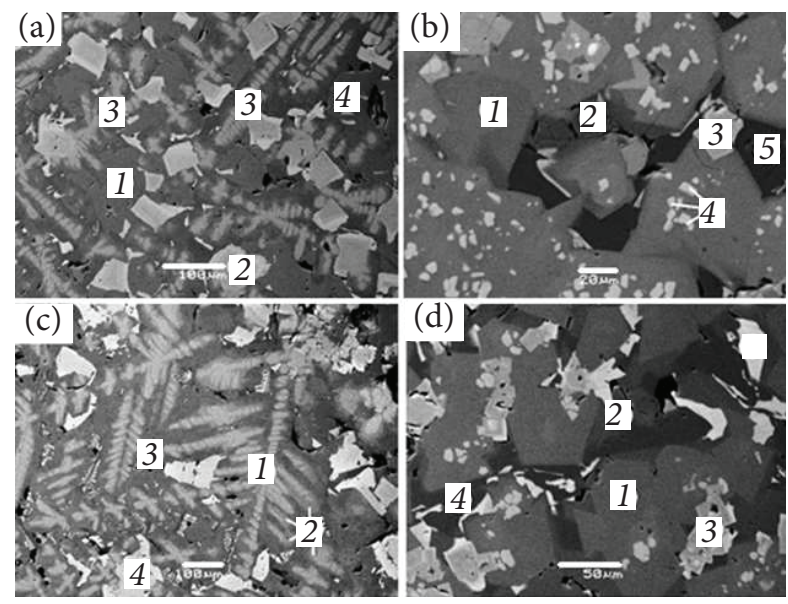

Fig. 1. SEM image of La (a: (1) murataite, (2) perovskite, (3) zirconolite, (4) crichtonite), $\mathrm{Nd}$ (b: $(1,2)$ murataite; (3) perovskite; (4) zirconolite; (5) crichtonite), Ce3 (c: (1) zirconolite, (2,3) murataite, (4) perovskite), Ce4 (d $(1,2)$ murataite, (3) perovskite, (4) crichtonite). Scale marks are equal to $(\mathrm{a}, \mathrm{c}) 100$, (b) 20 , and (d) $50 \mu \mathrm{m}$.

used to analyze Ln and An-containing glasses and ceramics [18-22], including those based on murataite. No information has been found in the literature on the XPS study of ceramics containing $\mathrm{La}, \mathrm{Ce}, \mathrm{Nd}$, and Ho. We have studied ceramics samples with $\mathrm{La}, \mathrm{Ce}, \mathrm{Nd}$, or Ho to determine the surface composition and predict their behavior during long-term storage and disposal. These elements were chosen due to the fact that $\mathrm{La}, \mathrm{Ce}$, and $\mathrm{Nd}$ dominate among the fission products in HLW. In addition, $\mathrm{Ce}$ in oxidation states III and IV serves as an imitator of actinides, for example, $\mathrm{Pu}(\mathrm{III})$ and $\mathrm{Pu}(\mathrm{IV})$. Holmium was introduced to study the effect of an element cation radius on the phase composition of ceramics with REE.

\section{EXPERIMENTAL}

The samples were synthesized in a VTP-12/15 furnace by melting mixtures of the following composition (wt \%): $50 \mathrm{TiO}_{2}, 10 \mathrm{CaO}, 10 \mathrm{MnO}_{2}, 5 \mathrm{Al}_{2} \mathrm{O}_{3}, 5 \mathrm{Fe}_{2} \mathrm{O}_{3}$, $10 \mathrm{ZrO}_{2}, 10 \mathrm{Ln}_{2} \mathrm{O}_{3}\left(\mathrm{Ln}=\mathrm{La}, \mathrm{Ce}, \mathrm{Nd}, \mathrm{Ho}\right.$ ) or $10 \mathrm{CeO}_{2}$ in glassy carbon crucibles at $1500^{\circ} \mathrm{C}$ for $0.5 \mathrm{~h}$ and cooling after the furnace turning off. They were studied by X-ray diffraction (XRD) and scanning electron microscopy (SEM/EDX); some of the results are reported in [23]. XPS spectra were recorded on a Kratos Axis Ultra DLD instrument using monochromatic $\mathrm{Al} K_{\alpha}$ radiation $(h v=$ $1486.7 \mathrm{eV}$ ) from $300 \times 700 \mu \mathrm{m}$ areas, which is tens of times larger than the grain size of the ceramics phases. To prepare an unoxidized surface, the samples were cleaved and immediately placed into the spectrometer. Binding energies $\left(E_{\mathrm{b}}\right)$ are measured relative to $E_{\mathrm{b}}$ of C $1 s$ electrons of hydrocarbons on the sample surface equal to $285.0 \mathrm{eV}$. The error in determining the binding energy and line width is less than $\pm 0.05 \mathrm{eV}$, the error in determining the peak intensity is not higher than $\pm 5 \%$. The background associated with secondary scattered electrons was subtracted by the Shirley method [24]. The composition was analyzed according to the method described in [25] to a depth of $10 \mathrm{~nm}[26,27]$.

\section{RESULTS AND DISCUSSION}

The structure of the samples is shown in Fig. 1, the relative amount and composition of the phases, in Tables 1 and 2. Lanthanides are distributed among murataite, zirconolite, perovskite, crichtonite. In the samples of $\mathrm{La}, \mathrm{Ce} 3, \mathrm{Ce} 4$, and $\mathrm{Nd}$, their highest concentrations are observed in perovskite therewith in the sample of $\mathrm{Ce} 4$ there are two types: with a low and high cerium content. The phase composition of ceramics with cerium is somewhat different: the $\mathrm{Ce} 3$ sample contains less amount of murataite and there is zirconolite. With a decrease in the radius of the $\mathrm{Ln}$ ion the amount of perovskite decreases and it is absent in the holmium sample. In the sample with holmium, the highest Ho content is observed in zirconolite. The main Ln concentrator in ceramics is murataite (all its modifications M5, M8, and M3), except for the La sample with the highest amount of perovskite.

The spectra of Ln ions in ceramics are a combination of their spectra in separate phases. The survey spectra of the samples contain lines of all elements, as well as Auger spectra of carbon (C KLL), oxygen (O KLL), and iron (Fe $L M M$ ) (Fig. 2). They can be divided into two parts: the low energy region (from 0 to $50 \mathrm{eV}$ ) of valence electrons and the region of core electrons (above $50 \mathrm{eV}$ ). Consider the structure of these regions in more detail.

The region of valence electrons. In the spectral range from 0 to $15 \mathrm{eV}$ the lines of outer electrons (OVMO) and in the range from 15 to $50 \mathrm{eV}$, of inner valence molecular orbitals (IVMO) are observed (Figs. 2a-2d, Table 3). The electron spectrum of the OVMO contains a number of peaks, but does not provide information on the sample composition. A weak maximum at $1.7 \mathrm{eV}$ (Fig. 3a) is associated with the Ce $4 f$ electrons, which do not participate in the chemical bonding of $\mathrm{Ce}^{3+}$ ions [28]. The lines of Ca $3 s^{-}, \mathrm{Mn} 3 p-, \mathrm{Zr} 4 s^{-}$, and $\mathrm{O} 2 s$-electrons are observed: their intensity can be used for qualitative and quantitative elemental analysis. 
Table 1. Target composition of the samples and the phases identified in them. XRD and SEM/EMF data

\begin{tabular}{c|c|c|c|c|c|c|l|l}
\hline \multirow{2}{*}{ Sample } & \multicolumn{7}{|c|}{ Component content, wt \% } & \multirow{2}{*}{$\begin{array}{c}\text { Phases and their ratio according to XRF and } \\
\text { SEM/EDS data }\end{array}$} \\
\cline { 2 - 7 } & $\mathrm{Al}_{2} \mathrm{O}_{3}$ & $\mathrm{CaO}$ & $\mathrm{TiO}_{2}$ & $\mathrm{MnO}$ & $\mathrm{Fe}_{2} \mathrm{O}_{3}$ & $\mathrm{ZrO}_{2}$ & \multicolumn{1}{|c|}{$\mathrm{Ln}_{2} \mathrm{O}_{3}$} & \\
\hline $\mathrm{La}$ & 5 & 10 & 50 & 10 & 5 & 10 & 10 & $\mathrm{Z} \sim \mathrm{M} \sim \mathrm{P}>\mathrm{C}>>\mathrm{P} / \mathrm{I}>\mathrm{R}$ \\
$\mathrm{Ce} 3$ & 5 & 10 & 50 & 10 & 5 & 10 & $10\left(\mathrm{Ce}_{2} \mathrm{O}_{3}\right)$ & $\mathrm{Z}>\mathrm{P} \sim \mathrm{M}>\mathrm{C}$ \\
$\mathrm{Ce} 4$ & 5 & 10 & 50 & 10 & 5 & 10 & $10\left(\mathrm{CeO}_{2}\right)$ & $\mathrm{M}>\mathrm{P}>\mathrm{C}>\mathrm{P} / \mathrm{I}$ \\
$\mathrm{Nd}$ & 5 & 10 & 50 & 10 & 5 & 10 & 10 & $\mathrm{M}>\mathrm{Z} \sim \mathrm{P}>\mathrm{C}$ \\
$\mathrm{Ho}$ & 5 & 10 & 50 & 10 & 5 & 10 & 10 & $\mathrm{M}>\mathrm{Z}>\mathrm{C}$ \\
\hline
\end{tabular}

a $(\mathrm{M})$ murataite (all modifications), $(\mathrm{P})$ perovskite, $(\mathrm{Z})$ zirconolite, $(\mathrm{C})$ crichtonite, $(\mathrm{P} / \mathrm{I})$ pyrophanite/ilmenite, $(\mathrm{R})$ rutile.

Table 2. Phase formulas in ceramic samples with lanthanides, SEM/EDS analysis data ${ }^{a}$

\begin{tabular}{|c|c|c|}
\hline Sample & Phase & Formulas calculated based on the charge of cations: $\mathrm{Ce}^{3+}, \mathrm{Fe}^{3+}$ and $\mathrm{Mn}^{3-}$ \\
\hline \multirow[t]{5}{*}{$\mathrm{La}$} & Zirconolite & {$\left[\left(\mathrm{Ca}_{0.46} \mathrm{La}_{0.03}\right) \mathrm{Zr}_{0.81}\left(\mathrm{Ti}_{1.89} \mathrm{Al}_{0.22} \mathrm{Mn}_{0.45} \mathrm{Fe}_{0.13}\right)\right]_{4.06 .90}$} \\
\hline & Murataite-5 & $\left(\mathrm{Ca}_{1.30} \mathrm{La}_{0.19} \mathrm{Zr}_{0.76} \mathrm{Ti}_{7.20} \mathrm{Al}_{2.23} \mathrm{Mn}_{2.17} \mathrm{Fe}_{1.20}\right)_{15.0} \mathrm{O}_{24.76}$ \\
\hline & Murataite-8 & $\left(\mathrm{Ca}_{0.76} \mathrm{La}_{0.88} \mathrm{Zr}_{0.42} \mathrm{Ti}_{16.57} \mathrm{Al}_{2.67} \mathrm{Mn}_{2.60} \mathrm{Fe}_{2.06}\right)_{26.0} \mathrm{O}_{45.81}$ \\
\hline & Perovskite & {$\left[\left(\mathrm{Ca}_{0.72} \mathrm{La}_{0.20}\right)\left(\mathrm{Ti}_{0.96} \mathrm{Al}_{0.03} \mathrm{Mn}_{0.01} \mathrm{Fe}_{0.01}\right)\right]_{1.92 \mathrm{O} .0}$} \\
\hline & Crichtonite & {$\left[\left(\mathrm{Ca}_{0.68} \mathrm{La}_{0.81}\right)\left(\mathrm{Zr}_{0.33} \mathrm{Ti}_{14.33} \mathrm{Al}_{1.64} \mathrm{Mn}_{2.12} \mathrm{Fe}_{1.49}\right)\right]_{21.39} \mathrm{O}_{38.0}$} \\
\hline \multirow[t]{5}{*}{$\mathrm{Ce} 3$} & Zirconolite & {$\left[\left(\mathrm{Ca}_{0.43} \mathrm{Ce}_{0.07}\right) \mathrm{Zr}_{0.83}\left(\mathrm{Ti}_{1.89} \mathrm{Al}_{0.18} \mathrm{Mn}_{0.46} \mathrm{Fe}_{0.13}\right)\right]_{4.0} \mathrm{O}_{6.93}$} \\
\hline & Murataite-5 & $\left(\mathrm{Ca}_{1.74} \mathrm{Ce}_{0.41} \mathrm{Zr}_{1.67} \mathrm{Al}_{1.22} \mathrm{Ti}_{7.70} \mathrm{Mn}_{1.75} \mathrm{Fe}_{0.50}\right)_{15.0} \mathrm{O}_{25.42}$ \\
\hline & Murataite- 8 & $\left(\mathrm{Ca}_{2.27} \mathrm{Ce}_{0.69} \mathrm{Zr}_{1.01} \mathrm{Ti}_{12.95} \mathrm{Al}_{4.11} \mathrm{Mn}_{3.17} \mathrm{Fe}_{1.80}\right)_{26.0} \mathrm{O}_{43.27}$ \\
\hline & Perovskite & $\left(\mathrm{Ca}_{0.61} \mathrm{Ce}_{0.24} \mathrm{Zr}_{0.01} \mathrm{Ti}_{0.95} \mathrm{Al}_{0.05} \mathrm{Mn}_{0.03}\right)_{1.89} \mathrm{O}_{3.0}$ \\
\hline & Crichtonite & $\left(\mathrm{Ca}_{0.84} \mathrm{Ce}_{0.74} \mathrm{Zr}_{0.24} \mathrm{Ti}_{14.44} \mathrm{Al}_{1.58} \mathrm{Mn}_{2.07} \mathrm{Fe}_{1.49}\right)_{21.41} \mathrm{O}_{38.0}$ \\
\hline \multirow[t]{5}{*}{$\mathrm{Ce} 4$} & Murataite-5 & $\left(\mathrm{Ca}_{1.62} \mathrm{Ce}_{0.32} \mathrm{Zr}_{1.51} \mathrm{Ti}_{7.32} \mathrm{Al}_{1.88} \mathrm{Mn}_{1.76} \mathrm{Fe}_{0.59}\right)_{15.0} \mathrm{O}_{25.21}$ \\
\hline & Murataite- 8 & $\left(\mathrm{Ca}_{0.88} \mathrm{Ce}_{0.81} \mathrm{Zr}_{0.41} \mathrm{Ti}_{17.08} \mathrm{Al}_{2.42} \mathrm{Mn}_{2.37} \mathrm{Fe}_{2.01}\right)_{26.0} \mathrm{O}_{46.15}$ \\
\hline & Perovskite 1 & {$\left[\left(\mathrm{Ca}_{0.69} \mathrm{Ce}_{0.19}\right)\left(\mathrm{Ti}_{0.95} \mathrm{Al}_{0.06} \mathrm{Mn}_{0.03}\right)\right]_{1.92} \mathrm{O}_{3.0}$} \\
\hline & Perovskite 2 & {$\left[\left(\mathrm{Ca}_{0.51} \mathrm{Ce}_{0.32}\right)\left(\mathrm{Ti}_{0.99} \mathrm{Mn}_{0.03} \mathrm{Fe}_{0.01}\right)\right]_{1.85} \mathrm{O}_{3.0}$} \\
\hline & Crichtonite & $\left(\mathrm{Ca}_{0.73} \mathrm{Ce}_{0.67} \mathrm{Zr}_{0.34} \mathrm{Ti}_{14.06} \mathrm{Al}_{2.0} \mathrm{Mn}_{1.95} \mathrm{Fe}_{1.66}\right)_{21.40} \mathrm{O}_{38.0}$ \\
\hline \multirow[t]{5}{*}{$\mathrm{Nd}$} & Zirconolite & {$\left[\left(\mathrm{Ca}_{0.52} \mathrm{Nd}_{0.16}\right) \mathrm{Zr}_{0.72}\left(\mathrm{Ti}_{1.89} \mathrm{Al}_{0.30} \mathrm{Mn}_{0.32} \mathrm{Fe}_{0.10}\right)\right]_{4.0} \mathrm{O}_{6.88}$} \\
\hline & Murataite-5 & $\left(\mathrm{Ca}_{2.21} \mathrm{Nd}_{0.98} \mathrm{Zr}_{3.12} \mathrm{Ti}_{7.23} \mathrm{Al}_{0.57} \mathrm{Mn}_{0.70} \mathrm{Fe}_{0.20}\right)_{15.0} \mathrm{O}_{26.20}$ \\
\hline & Murataite-8 & $\left(\mathrm{Ca}_{2.88} \mathrm{Nd}_{0.88} \mathrm{Zr}_{1.74} \mathrm{Ti}_{13.73} \mathrm{Al}_{2.39} \mathrm{Mr}_{3.08} \mathrm{Fe}_{1.31}\right)_{26.0} \mathrm{O}_{43.76}$ \\
\hline & Perovskite & {$\left[\left(\mathrm{Ca}_{0.58} \mathrm{Nd}_{0.14}\right)\left(\mathrm{Ti}_{0.93} \mathrm{Al}_{0.14} \mathrm{Mn}_{0.07} \mathrm{Fe}_{0.04}\right)\right]_{1.91} \mathrm{O}_{3.0}$} \\
\hline & Crichtonite & $\left(\mathrm{Mn}_{2.91} \mathrm{Fe}_{2.98} \mathrm{Ti}_{14.28} \mathrm{Al}_{1.43}\right)_{21.60} \mathrm{O}_{38.0}$ \\
\hline \multirow[t]{5}{*}{ Ho } & Zirconolite & {$\left[\left(\mathrm{Ca}_{0.50} \mathrm{Ho}_{0.48}\right) \mathrm{Zr}_{0.81}\left(\mathrm{Ti}_{1.97} \mathrm{Mn}_{0.20} \mathrm{Fe}_{0.05}\right)\right]_{4.0} \mathrm{O}_{7.04}$} \\
\hline & Murataite-5 & $\left(\mathrm{Ca}_{3.10} \mathrm{Ho}_{1.15} \mathrm{Zr}_{1.98} \mathrm{Ti}_{13.37} \mathrm{Al}_{2.71} \mathrm{Mn}_{2.72} \mathrm{Fe}_{0.94}\right)_{26.0} \mathrm{O}_{43.76}$ \\
\hline & Murataite- 8 & $\left(\mathrm{Ca}_{1.33} \mathrm{Ho}_{0.11} \mathrm{Zr}_{0.23} \mathrm{Ti}_{5.88} \mathrm{Al}_{1.40} \mathrm{Mn}_{1.17} \mathrm{Fe}_{0.87}\right)_{11.0} \mathrm{O}_{18.31}$ \\
\hline & Perovskite & $\left(\mathrm{Ca}_{0.80} \mathrm{Ti}_{1.0} \mathrm{Mn}_{0.09} \mathrm{Fe}_{0.03} \mathrm{Zr}_{0.01} \mathrm{Ho}_{0.04}\right)_{1.96} \mathrm{O}_{3.0}$ \\
\hline & Crichtonite & $\left(\mathrm{Ca}_{3.26} \mathrm{Ho}_{0.19} \mathrm{Zr}_{0.32} \mathrm{Ti}_{12.85} \mathrm{Al}_{2.34} \mathrm{Mn}_{2.21} \mathrm{Fe}_{1.55}\right)_{22.77} \mathrm{O}_{38.0}$ \\
\hline
\end{tabular}

\footnotetext{
${ }^{\mathrm{a}}$ In the $\mathrm{La}, \mathrm{Ce} 4$, Ho samples there is also pyrophanite-ilmenite of $\left(\mathrm{Fe}_{0.4} \mathrm{Mn}_{0.6}\right) \mathrm{TiO}_{3}$ composition and in the La sample in addition there are
} rutile. 
Table 3. Electron binding energies $\left(E_{\mathrm{b}}{ }^{\mathrm{a}}, \mathrm{eV}\right)$ and line widths $\left(\Gamma^{\mathrm{b}}, \mathrm{eV}\right)$ of sample spectra

\begin{tabular}{|c|c|c|c|c|c|c|c|c|c|c|}
\hline Sample & $\mathrm{MO}$ & $\mathrm{Al} 2 p$ & $\operatorname{Zr} 3 d_{5 / 2}$ & $\mathrm{Ca} 2 p_{3 / 2}$ & Ti $2 p_{3 / 2}$ & $\operatorname{Mn} 2 p_{3 / 2}$ & $\begin{array}{c}\mathrm{Fe}^{2+} 2 p_{3 / 2} \\
\mathrm{Fe}^{3+} 2 p_{3 / 2}\end{array}$ & $\operatorname{Ln} 3 d_{5 / 2}$ & $\mathrm{O} 1 s$ & C $1 s$ \\
\hline $\mathrm{La}$ & $\begin{array}{l}5.0,7.0,17.8, \\
20.6,22.6,25.5, \\
30.8,37.6,44.0, \\
48.6\end{array}$ & $\begin{array}{l}74.3 \\
(1.2)\end{array}$ & $\begin{array}{l}182.6 \\
(1.1)\end{array}$ & $\begin{array}{l}347.4 \\
(1.5)\end{array}$ & $\begin{array}{l}458.9 \\
(1.3)\end{array}$ & $\begin{array}{l}641.4 \\
(2.4) \\
4.6 \mathrm{sat}_{1} \\
(48 \%)\end{array}$ & $\begin{array}{l}708.8(1.7), \\
710.7(3.0)\end{array}$ & $\begin{array}{l}834.8 \\
(2.1) \\
4.0 \mathrm{sat} \\
(82 \%)\end{array}$ & $\begin{array}{l}530.3 \\
(1.2) \\
531.9 \\
(1.3)\end{array}$ & $\begin{array}{l}285.0 \\
(1.3) \\
289.0 \\
(2.1)\end{array}$ \\
\hline $\mathrm{Ce} 3$ & $\begin{array}{l}1.7,4.9,7.3,18.1 \\
20.8,22.6,25.2, \\
30.8,37.4,43.7 \\
48.6\end{array}$ & $\begin{array}{l}74.4 \\
(1.4)\end{array}$ & $\begin{array}{l}182.6 \\
(1.3)\end{array}$ & $\begin{array}{l}347.0 \\
(1.5)\end{array}$ & $\begin{array}{l}458.4 \\
(1.4)\end{array}$ & $\begin{array}{l}641.3 \\
(2.5), \\
1.7 \mathrm{sat}_{1} \\
(21 \%), \\
5.8 \mathrm{sat}_{2} \\
(43 \%)\end{array}$ & $\begin{array}{l}709.1(1.7) \\
711.0(3.0)\end{array}$ & $\begin{array}{l}881.6 \\
(3.2) \\
4.0 \text { sat } \\
(133 \%)\end{array}$ & $\begin{array}{l}530.2 \\
(1.4), \\
531.6 \\
(1.5)\end{array}$ & $\begin{array}{l}285.0 \\
(1.3) \\
289.1 \\
(1.6)\end{array}$ \\
\hline $\mathrm{Ce} 4$ & $\begin{array}{l}1.9,4.9,7.318 .1 \\
20.9,22.5,25.2, \\
30.7,37.4,43.7 \\
48.7\end{array}$ & $\begin{array}{l}74.3 \\
(1.4)\end{array}$ & $\begin{array}{l}182.6 \\
(1.2)\end{array}$ & $\begin{array}{l}347.0 \\
(1.6)\end{array}$ & $\begin{array}{l}458.8 \\
(1.4)\end{array}$ & $\begin{array}{l}641.5 \\
(2.6) \\
4.3 \mathrm{sat}_{1} \\
(44 \%)\end{array}$ & $\begin{array}{l}709.0(1.7), \\
711.0(3.0)\end{array}$ & $\begin{array}{l}881.6 \\
(2.9) \\
4.0 \text { sat } \\
(173 \%)\end{array}$ & $\begin{array}{l}530.2 \\
(1.4), \\
531.6 \\
(1.5)\end{array}$ & $\begin{array}{l}285.0 \\
(1.3) \\
288.9 \\
(1.6)\end{array}$ \\
\hline $\mathrm{Nd}^{\mathrm{c}}$ & $\begin{array}{l}4.9,7.4,19.6, \\
22.4,25.3,30.7 \\
37.5,43.8,48.6 \\
50.8\end{array}$ & $\begin{array}{l}74.2 \\
(1.3)\end{array}$ & $\begin{array}{l}182.6 \\
(1.1)\end{array}$ & $\begin{array}{l}347.1 \\
(1.5)\end{array}$ & $\begin{array}{l}458.8 \\
(1.4)\end{array}$ & $\begin{array}{l}641.4 \\
(2.5) \\
4.6 \mathrm{sat}_{1} \\
(53 \%)\end{array}$ & $\begin{array}{l}709.0(1.7), \\
710.6(3.0)\end{array}$ & $\begin{array}{l}- \\
982.1 \\
(5.0)\end{array}$ & $\begin{array}{l}530.2 \\
(1.3) \\
531.7 \\
(1.4)\end{array}$ & $\begin{array}{l}285.0 \\
(1.3) \\
288.9 \\
(1.8)\end{array}$ \\
\hline $\mathrm{Ho}^{\mathrm{d}}$ & $\begin{array}{l}4.5,6.9,10.3, \\
19.5,22.1,25.1 \\
30.6,37.4,43.5 \\
48.5,50.9\end{array}$ & $\begin{array}{l}74.1 \\
(1.3)\end{array}$ & $\begin{array}{l}182.6 \\
(1.1)\end{array}$ & $\begin{array}{l}346.9 \\
(1.5)\end{array}$ & $\begin{array}{l}458.7 \\
(1.3)\end{array}$ & $\begin{array}{l}641.4 \\
(2.6) \\
5.4 \mathrm{sat}_{1} \\
(34 \%)\end{array}$ & $\begin{array}{l}708.8(1.7), \\
710.5(3.0)\end{array}$ & $\begin{array}{l}1352.5 \\
(3.9)\end{array}$ & $\begin{array}{l}530.2 \\
(1.3) \\
531.7 \\
(1.4)\end{array}$ & $\begin{array}{l}285.0 \\
(1.3) \\
288.9 \\
(1.5)\end{array}$ \\
\hline
\end{tabular}

${ }^{\mathrm{a}} E_{\mathrm{b}}$ is given with respect to $E_{\mathrm{b}}(\mathrm{C} 1 s)=285.0 \mathrm{eV}$;

${ }^{\mathrm{b}} \Gamma$ are given in paratheses.

${ }^{\mathrm{c}}$ Binding energies of $\mathrm{Nd} 4 d$-electrones are 122.5 (2.3) and $125.2(2.9) \mathrm{eV}$.

${ }^{\mathrm{d}}$ Binding energies of Ho $4 d$-electrones are 161.1(2.6), 163.4(1.8 ), 166.8(4.9) eV.

Core electron region. The elemental and ionic composition can be determined based on the intensities, energies, and structure of the core electron lines (Table 3): Mn 2p- (Fig. 4a), Fe $2 p$ - (Fig. 4b), C $1 s-$ (Fig. 4c), Zr 3d- (Fig. 4d), and Al 2p- (Fig. 5a), O $1 s-$ (Fig. 5b), Ca $2 p$ - (Fig. 5c), Ti $2 p$ - (Fig. 5d) electrons. The structure of the spectrum of Mn $2 p$ electrons (Fig. 4 a) is typical of $\mathrm{Mn}^{3+}$ [29]. The spectrum of Fe $2 p$ electrons of the samples has a complex structure (Fig. 4b); instead of a spin doublet with $\Delta E_{\mathrm{sl}}=13.1 \mathrm{eV}$, a superposition of the spectra of $\mathrm{Fe}^{2+}$ and $\mathrm{Fe}^{3+}$ ions is observed [30]. There are components of this doublet for $\mathrm{Fe}^{2+}$ in the total spectrum as a shoulder on the complex structure of the $\mathrm{Fe}^{3+}$ spectrum in the region of lower binding energy at $E_{\mathrm{b}}\left(\mathrm{Fe} 2 p_{3 / 2}\right)=709.1 \mathrm{eV}$ with $\Gamma\left(\mathrm{Fe} 2 p_{3 / 2}\right)=1.7 \mathrm{eV}$ (Fig. $4 \mathrm{~b}$ ). $\mathrm{Fe}^{3+}$ dominates in the samples; its amount is 92-94 rel \%.

In the spectrum of $\mathrm{C} 1 \mathrm{~s}$ electrons of carbon on the sample surface there is a line of the $\mathrm{CO}_{3}^{2-}$-group
(Fig. 4c). The spectrum of $\mathrm{Zr} 3 d$ electrons consists of a doublet with $\Delta E_{\mathrm{sl}}(\mathrm{Zr} 3 d)=2.4 \mathrm{eV}$ (Table 3, Fig. 4d). The binding energy of $\mathrm{Zr} 3 d_{5 / 2}$ electrons is close to the value for $\mathrm{ZrO}_{2}$, equal to $182.6 \mathrm{eV}$ [26].

The binding energy of $\mathrm{Al} 2 p$ electrons for the studied ceramics is comparable to the value for $\mathrm{Al}_{2} \mathrm{O}_{3}$ [12] (Fig. 5a), for the Ca $2 p_{3 / 2}$ electrons (Fig. 5c) it is approximately $346.0 \mathrm{eV}$, which is typical of $\mathrm{CaO}[25$ ], and for the Ti $2 p_{3 / 2}$ electrons (Fig. 5d) the binding energy depends little on the composition of the samples (Table 3). The spectrum of $\mathrm{O} 1 \mathrm{~s}$ electrons consists of two lines (Fig. 5b, Table 3) at 530.2 and $531.6 \mathrm{eV}$ with intensities of 85 and $15 \%$, respectively. Taking into account Eq. (1) [25] the lengths of the element-oxygen $\mathrm{R}_{\mathrm{E}-\mathrm{O}}$ bonds are determined as 0.210 and $0.186 \mathrm{~nm}$ :

$$
\mathrm{R}_{\mathrm{E}-\mathrm{O}}(\mathrm{nm})=2.27\left(E_{\mathrm{b}}-519.4\right)^{-1} .
$$

These values characterize the lengths of the elementoxygen bonds in the bulk of the studied samples and on their surfaces. It is assumed that the value of $0.210 \mathrm{~nm}$ is 


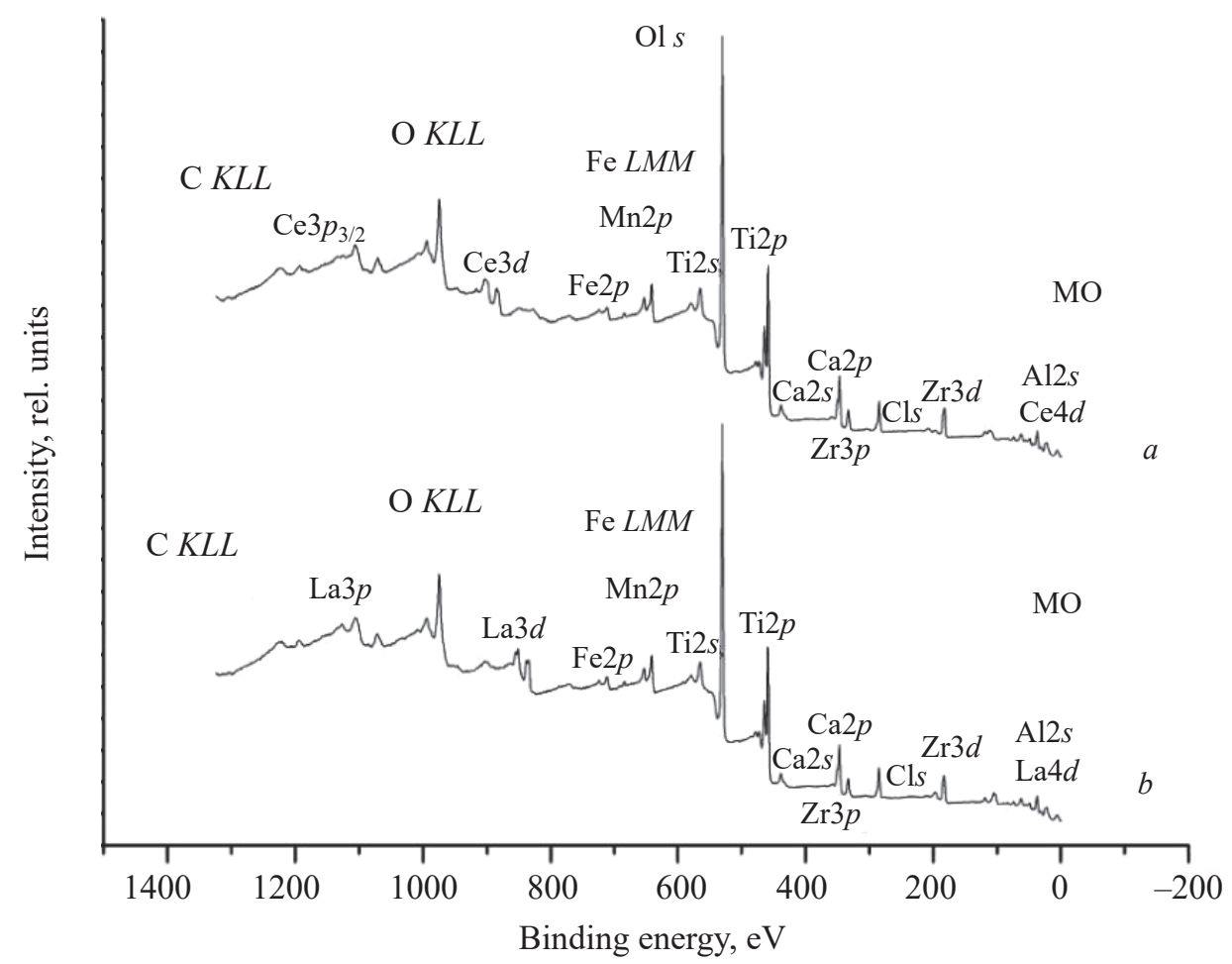

Fig. 2. Survey spectra of ceramics using the example of (a) Ce4 and (b) La samples.

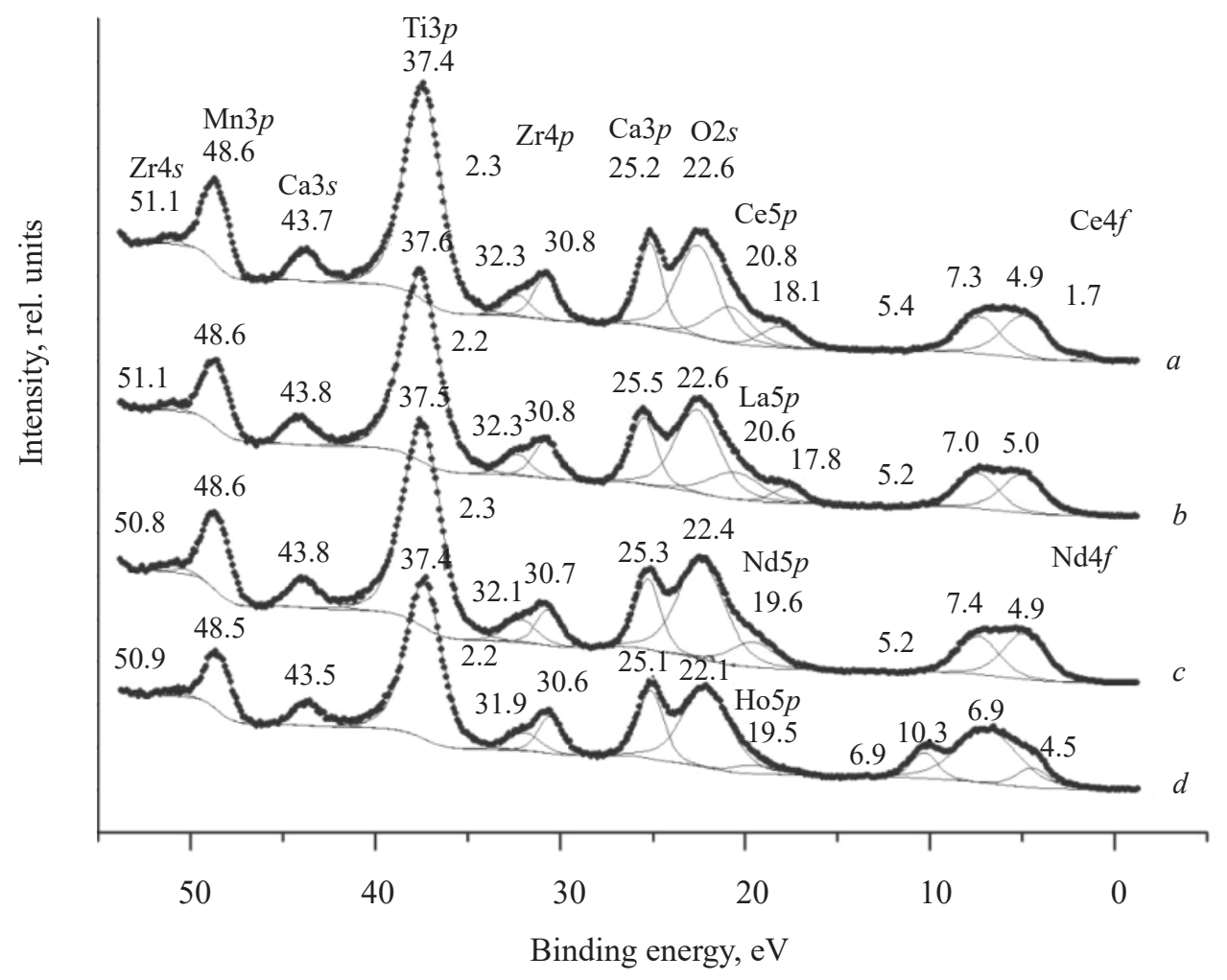

Fig. 3. Valence electron spectra of (a) Ce4, (b) La, (c) Nd, and (d) Ho ceramics. 

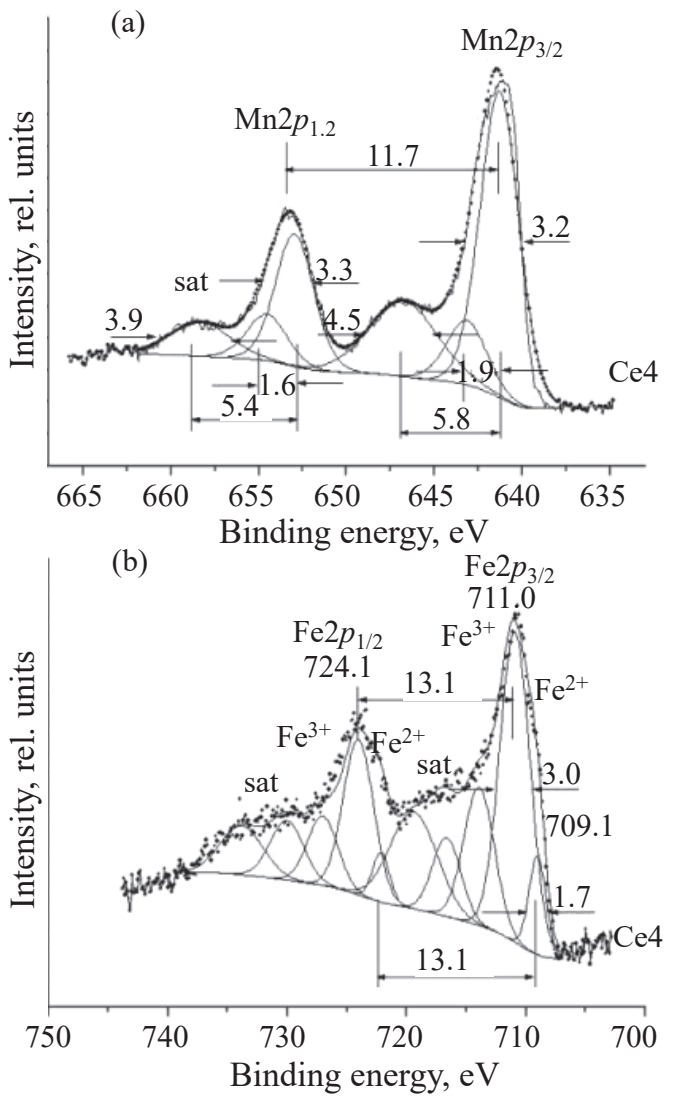
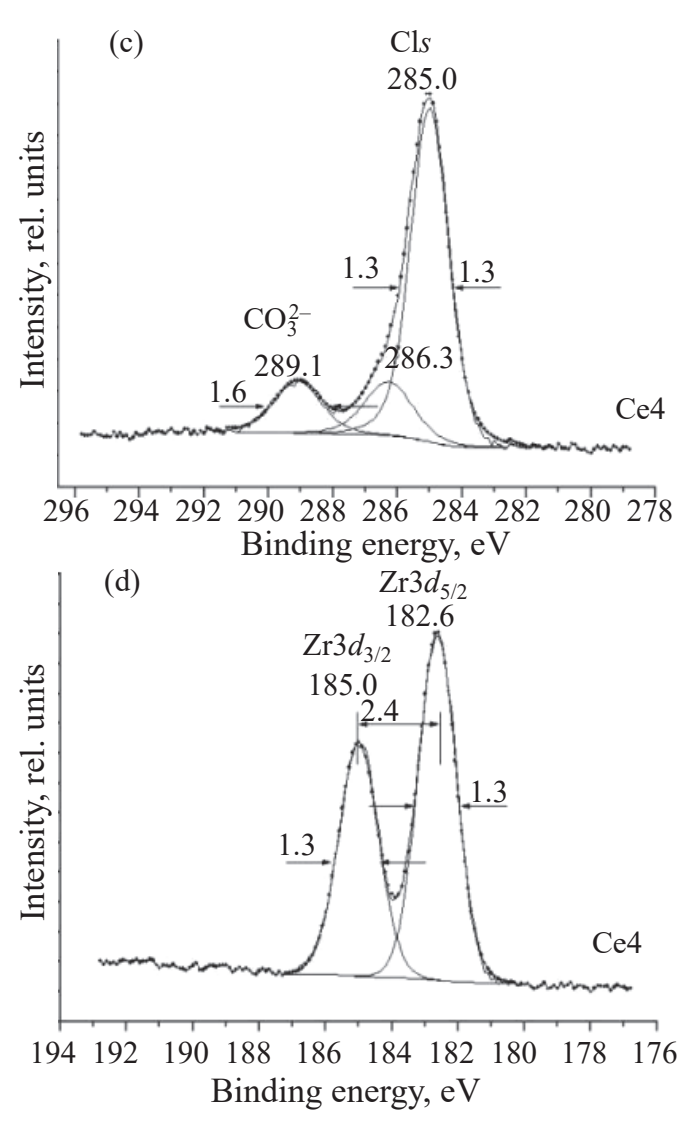

Fig. 4. Spectra of (a) $\mathrm{Al} 2 p$-, (b) $\mathrm{O} 1 s-$, (c) Ca 2p-, and (d) Ti $2 p$-electrons of Ce4 ceramics.

averaged for the bond lengths of oxygen and metals (Al$\mathrm{O}, \mathrm{Ca}-\mathrm{O}, \mathrm{Ti}-\mathrm{O}, \mathrm{Mn}-\mathrm{O}, \mathrm{Fe}-\mathrm{O}, \mathrm{Zr}-\mathrm{O}, \mathrm{Ln}-\mathrm{O})$ present in the sample, and the value $0.186 \mathrm{~nm}$ refers to the bonds of metals with hydroxyl groups adsorbed on the surface from the environment.

The structure of the La $3 d$-electron spectrum of the $\mathrm{La}$ sample is due to spin-orbit splitting with $\Delta E_{\mathrm{sl}}=16.8 \mathrm{eV}$ [31] and many-body perturbation (Fig. 6a, Table 3) and is typical for the $\mathrm{La}^{3+}$ cation [14].

The structure of the spectra of Ce $3 d$ electrons of the $\mathrm{Ce} 3$ and $\mathrm{Ce} 4$ samples is typical of a mixture of $\mathrm{Ce}^{3+}$ and $\mathrm{Ce}^{4+}$ ions (Figs. 6b, 6c). In [28], an original technique was proposed, which makes it possible to determine the ionic composition of the sample surface (the ratio of the $\mathrm{Ce}^{3+}$ and $\mathrm{Ce}^{4+}$ ) based on the intensity of a single line of the spectrum of $\mathrm{Ce} 3 d$ electrons at $916.8 \mathrm{eV}$. It was found that the $\mathrm{Ce} 4$ sample contains $25 \mathrm{rel} \% \mathrm{Ce}^{4+}$ and $75 \mathrm{rel} \% \mathrm{Ce}^{3+}$, and $\mathrm{Ce} 3$ contains, $26 \mathrm{rel} \% \mathrm{Ce}^{4+}$ and $74 \mathrm{rel} \% \mathrm{Ce}^{3+}$. The $\mathrm{Ce}^{3+}$ state dominates regardless of the form in which the element $\left(\mathrm{CeO}_{2}\right.$ or $\left.\mathrm{Ce}_{2} \mathrm{O}_{3}\right)$ was introduced into the charge. This fact agrees with the
X-ray absorption spectroscopy (XAS) data, according to which cerium in these samples there is predominantly in the $\mathrm{Ce}^{3+}$ state [23].

The complex structure of the spectrum of $\mathrm{Nd} 3 d$ electrons for the $\mathrm{Nd}$ sample, caused by spin-orbit splitting with $\Delta E_{\mathrm{sl}}=22.2 \mathrm{eV}$ [14], multiplet splitting, and multielectron excitation, is superimposed on the structure of the $\mathrm{O} K L L$ Auger spectrum of oxygen (Fig. 7c). Despite this fact, it was possible to determine the binding energies of electrons of the spin doublet lines, equal to $E_{\mathrm{b}}\left(\mathrm{Nd} 3 d_{5 / 2}\right)=982.1 \mathrm{eV}$ and $E_{\mathrm{b}}\left(\mathrm{Nd} 3 d_{3 / 2}\right)=$ $1005.2 \mathrm{eV}$, which are characteristic of $\mathrm{Nd}^{3+}$ in $\mathrm{Nd}_{2} \mathrm{O}_{3}$ [14] (Fig. 7c, Table 3). The spectrum of Nd $4 d$ electrons with $\Delta E_{\mathrm{sl}}=9.9 \mathrm{eV}$ [32] is superimposed on the spectrum of aluminum Al $2 s$ (Fig. 7a). However, the observed two maxima at 122.5 and $125.2 \mathrm{eV}$ are characteristic of the $\mathrm{Nd} 4 d$ electrons of the $\mathrm{Nd}^{3+}$ cation in $\mathrm{Nd}_{2} \mathrm{O}_{3}$ [14].

The spectrum of Ho $3 d_{5 / 2}$ electrons of the Ho sample with $\Delta E_{\mathrm{sl}}=40.1 \mathrm{eV}$ [31] is observed at a weighted average binding energy of $1351.2 \mathrm{eV}$ (Fig. 7d). There is a maximum at $1352.5 \mathrm{eV}$, which corresponds to the bind- 

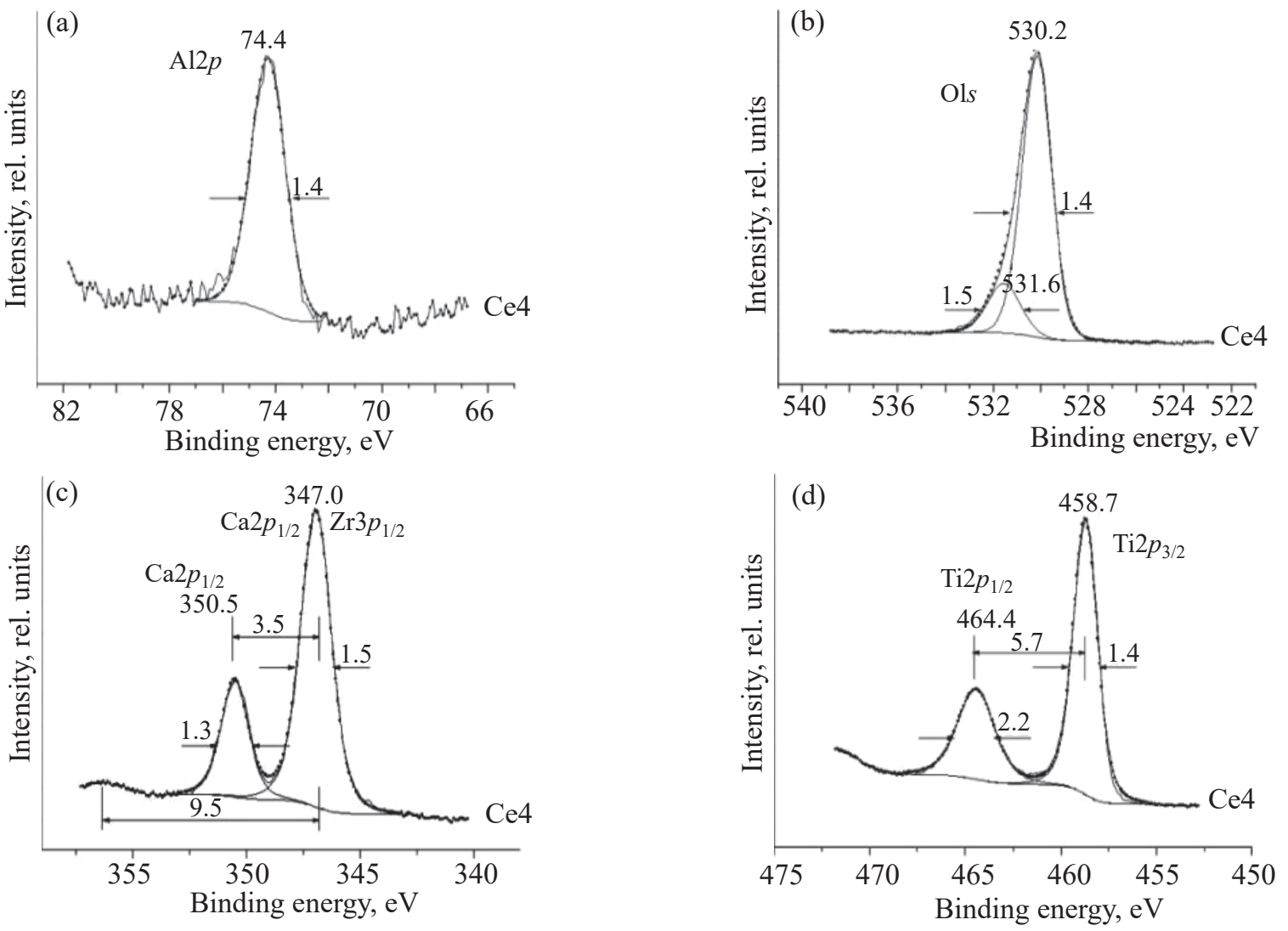

Fig. 5. Spectra of (a) Al2p, (b) Ols, (c) Ca2p-and (d) Ca2p-electrones of Ce4 ceramics.
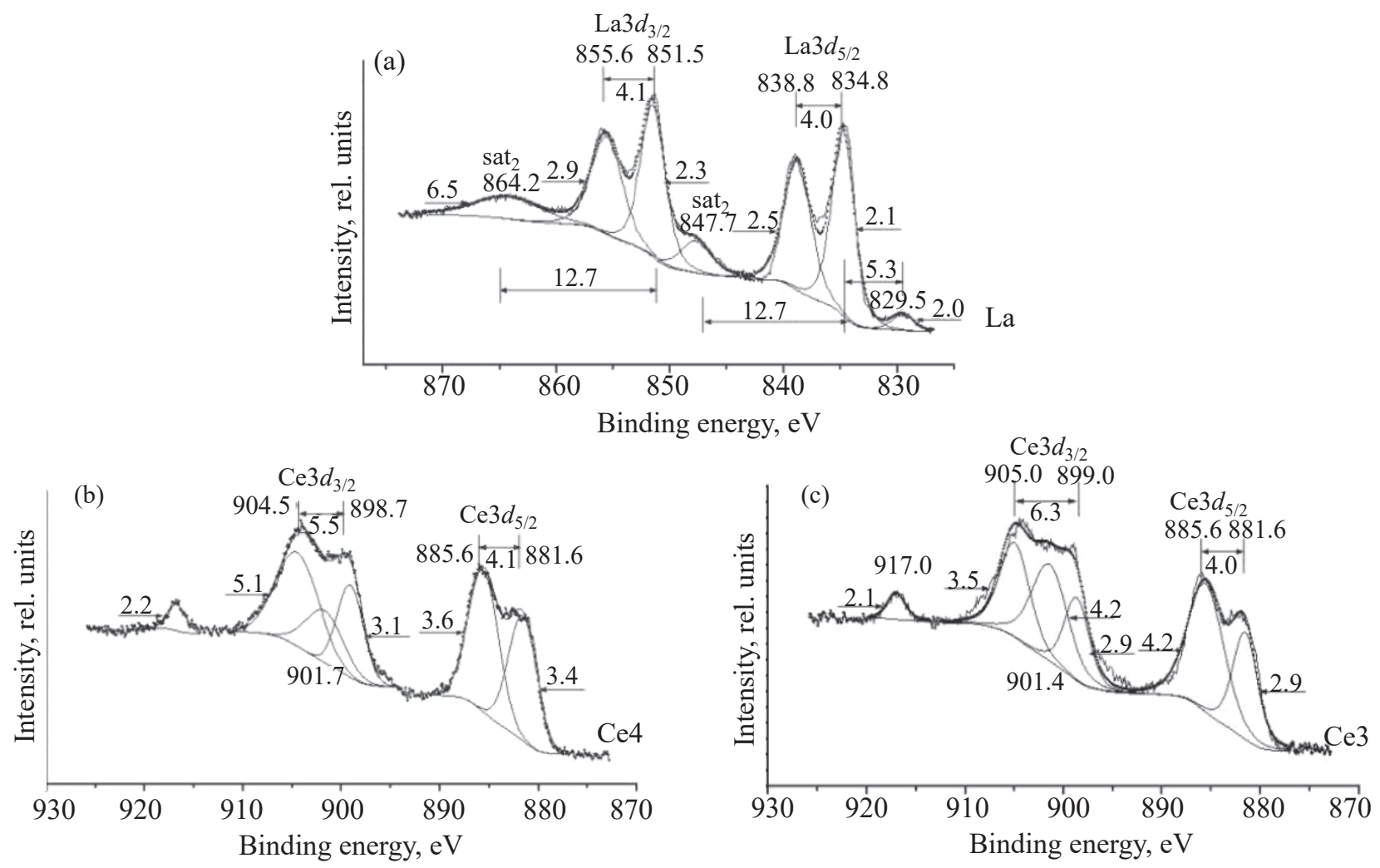

Fig. 6. REE spectra of $3 d$ electrons ( $\mathrm{La}$ or $\mathrm{Ce}$ ) for (a) $\mathrm{La}$, (b) $\mathrm{Ce} 3$, and (c) $\mathrm{Ce} 4$ ceramics. 


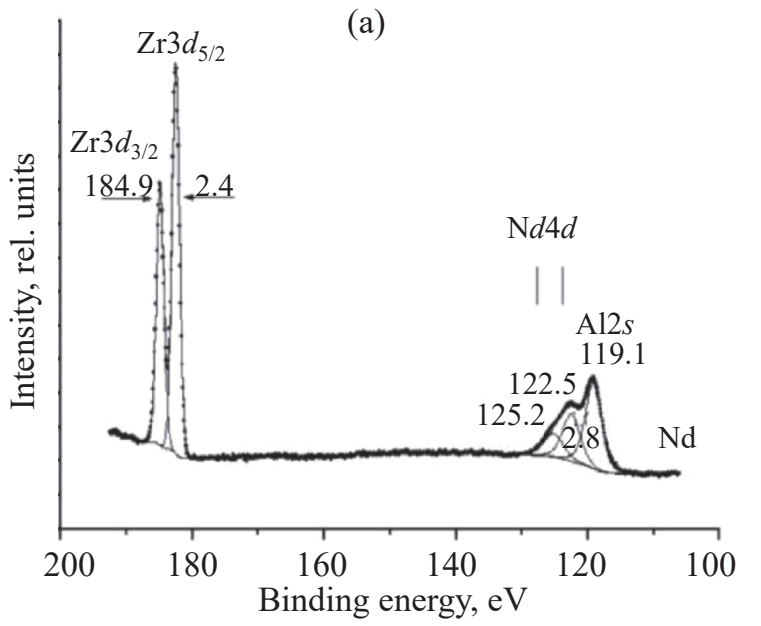

(b)

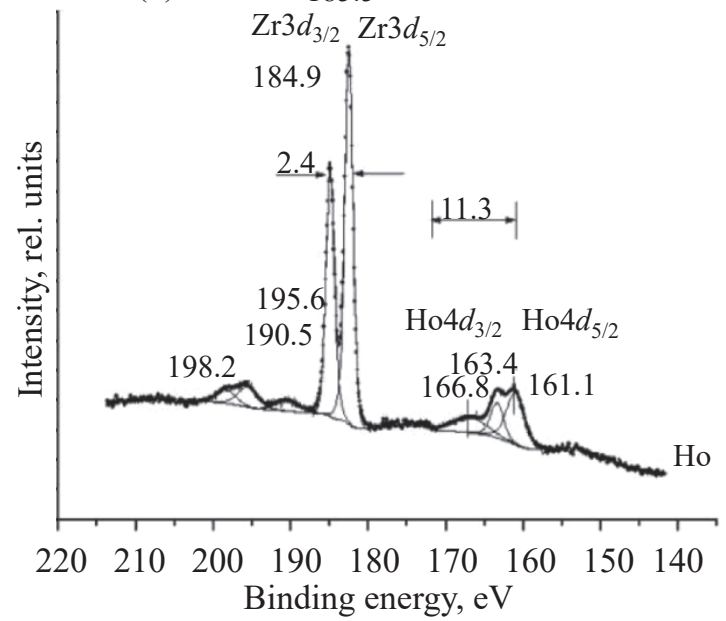

(c)

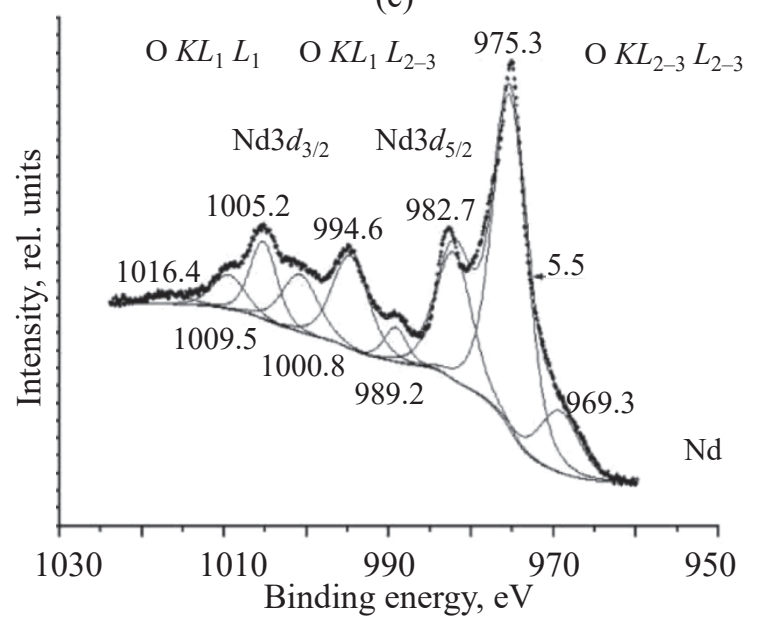

(d)

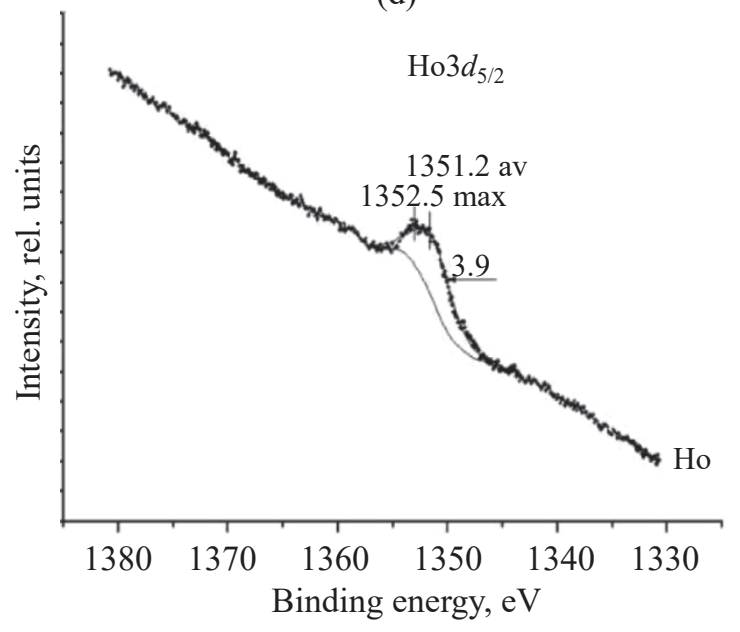

Fig. 7. Spectra of (a) Nd $4 d$ and (b) Ho $4 d$ electrons, and (c) Nd $3 d$ and (d) Ho $3 d$ electrons for ceramics with neodymium (Nd sample) and holmium (Ho sample).

ing energy of $\mathrm{Ho} 3 d_{5 / 2}$ electrons in $\mathrm{Ho}_{2} \mathrm{O}_{3}$. The observed maxima in the spectrum agree with the data for $\mathrm{Ho}^{3+}$ in $\mathrm{Ho}_{2} \mathrm{O}_{3}$ [14]. The structure of the spectrum of $\mathrm{Ho} 4 d$ electrons of the Ho sample with $\Delta E_{\mathrm{sl}}=11.3 \mathrm{eV}$ [32] partially overlaps with the spectrum of $3 d$ electrons of $\mathrm{Zr}$ (Fig. 7b). Therefore, the intensity of the spectral lines of $4 d$ electrons and the holmium content are determined with a large error. When detecting the oxidation state of metals in the studied ceramics samples, the data of [33] were used.

The XPS method allows the analysis of the composition and valence state of elements on the sample surface to a depth of $10 \mathrm{~nm}$ [27]. This makes it indispensable in the analysis of changes in matrices after interaction with a solution [34]. The question remains to what extent the data for this layer can be extended to bulk of the ceramics. There is some discrepancy between the XPS and XAS results of the samples, manifested in a smaller share of oxidized forms of $\mathrm{Ce}$ and $\mathrm{U}$ when analyzed by the XAS method $[22,23]$. This fact may be due to the oxidation of elements on the sample surface during storage in air. When studying brannerite, it was shown that the share of such uranium is estimated at $10 \%$ of its total amount [35]. To reduce the influence of this factor, a fresh cleavage of the bulk sample was made before the XPS study. Another reason for the differences between the XPS and XAS data is a more rough estimate of the ratio of oxidation states by the XAS method. Therefore, XPS gives a more correct estimate of the contents of cations of different valences. The study of Ce-brannerite showed [36] that the discrepancy between the XPS data for the sample surface and the XAS data for the volume is relatively small. Note that data on the composition and valence of elements in the surface layer is very im- 
Table 4. Elemental composition of the surface of the studied samples according to XPS data and their target bulk composition normalized to one zirconium atom ${ }^{\text {a }}$

\begin{tabular}{c|l|l}
\hline Sample & \multicolumn{1}{|c}{ Data type } & \multicolumn{1}{c}{ Elemental composition per 1 Zr atom } \\
\hline La & XRS, surface & $\mathrm{Al}_{1.24} \mathrm{Ca}_{1.79} \mathrm{Ti}_{6.47} \mathrm{Mn}_{2.32} \mathrm{Fe}_{1.10} \mathrm{Zr}_{1.00} \mathrm{La}_{1.17} \mathrm{O}_{22.65+3.22} \mathrm{C}_{5.13+1.02}$ \\
& Bulk composition & $\mathrm{Al}_{1.22} \mathrm{Ca}_{2.20} \mathrm{Ti}_{7.75} \mathrm{Mn}_{1.43} \mathrm{Fe}_{0.77} \mathrm{Zr}_{1.00} \mathrm{La}_{0.75} \mathrm{O}_{26.7}$ \\
$\mathrm{Ce} 3$ & XRS, surface & $\mathrm{Al}_{1.27} \mathrm{Ca}_{1.72} \mathrm{Ti}_{6.62} \mathrm{Mn}_{2.57} \mathrm{Fe}_{1.41} \mathrm{Zr}_{1.00} \mathrm{Ce}_{0.92} \mathrm{O}_{22.23+5.22} \mathrm{C}_{8.53+0.96}$ \\
& Bulk composition & $\mathrm{Al}_{1.22} \mathrm{Ca}_{2.20} \mathrm{Ti}_{7.76} \mathrm{Mn}_{1.43} \mathrm{Fe}_{0.78} \mathrm{Zr}_{1.00} \mathrm{Ce}_{0.70} \mathrm{O}_{29.80}$ \\
$\mathrm{Ce} 4$ & XRS, surface & $\mathrm{Al}_{1.28} \mathrm{Ca}_{1.78} \mathrm{Ti}_{6.36} \mathrm{Mn}_{2.18} \mathrm{Fe}_{1.27} \mathrm{Zr}_{1.00} \mathrm{Ce}_{0.64} \mathrm{O}_{20.87+3.93} \mathrm{C}_{6.50+1.00}$ \\
$\mathrm{Nd}$ & Bulk composition & $\mathrm{Al}_{1.23} \mathrm{Ca}_{2.21} \mathrm{Ti}_{7.77} \mathrm{Mn}_{1.43} \mathrm{Fe}_{0.78} \mathrm{Zr}_{1.00} \mathrm{Ce}_{0.72} \mathrm{O}_{27.07}$ \\
$\mathrm{NRS}$, surface & $\mathrm{Al}_{1.27} \mathrm{Ca}_{1.77} \mathrm{Ti}_{6.74} \mathrm{Mn}_{2.47} \mathrm{Fe}_{0.93} \mathrm{Zr}_{1.00} \mathrm{Nd}_{0.80} \mathrm{O}_{22.49+3.32} \mathrm{C}_{6.46+0.93}$ \\
$\mathrm{Ho}$ & Bulk composition & $\mathrm{Al}_{1.23} \mathrm{Ca}_{2.20} \mathrm{Ti}_{7.76} \mathrm{Mn}_{1.43} \mathrm{Fe}_{0.77} \mathrm{Zr}_{1.00} \mathrm{Nd}_{0.74} \mathrm{O}_{26.71}$ \\
& XRS, surface & $\mathrm{Al}_{1.20} \mathrm{Ca}_{1.70} \mathrm{Ti}_{6.55} \mathrm{Mn}_{1.83} \mathrm{Fe}_{0.99} \mathrm{Zr}_{1.00} \mathrm{Ho}_{0.70} \mathrm{O}_{23.18+3.47} \mathrm{C}_{5.37+0.79}$ \\
\hline
\end{tabular}

a The composition is given for two chemical states for oxygen and carbon (Figs. 4, 5).

portant, since this region of the matrix is exposed to the solution. Leaching from matrices of variable valence elements (III, IV) is higher in cations of lower charge and higher basicity, i.e., in $\mathrm{Ce}^{3+}$ and $\mathrm{Pu}^{3+}$, and their ability to form complexes is lower than that of $\mathrm{Ce}^{4+}$ and $\mathrm{Pu}^{4+}[37$, 38]. According to XPS data, the surface composition of the samples (Table 4) is somewhat different from the bulk composition of ceramics (Table 1). Further sample studies are required to understand the exact reasons for this discrepancy.

\section{CONCLUSIONS}

Samples of a potential matrix for the immobilization of actinides and lanthanides, consisting mainly of murataite, zirconolite, and perovskite, have been studied. The XPS method was employed to determine the composition and valence state of elements in the surface layer of samples up to $10 \mathrm{~nm}$ thick. The content of $\mathrm{Mn}$ and $\mathrm{Fe}$ therein is higher, that of $\mathrm{Ca}$ and $\mathrm{Ti}$ is lower than in the bulk compositions in the samples. The ratio of $\mathrm{Ce}^{3+}$ and $\mathrm{Ce}^{4+}$ in the samples is $3: 1$ regardless of the form of cerium introduction into the charge. Iron is in the form of $\mathrm{Fe}^{3+}(92-94 \mathrm{rel} \%)$ and $\mathrm{Fe}^{2+}(6-8$ rel \%), and manganese is present in the $\mathrm{Mn}^{3+}$ state. The average bond length of $\mathrm{Al}-\mathrm{O}, \mathrm{Ca}-\mathrm{O}, \mathrm{Ti}-\mathrm{O}, \mathrm{Mn}-\mathrm{O}, \mathrm{Fe}-\mathrm{O}, \mathrm{Zr}-\mathrm{O}$, $\mathrm{Ln}-\mathrm{O}$ was estimated as $0.210 \mathrm{~nm}$.

\section{FUNDING}

The study was carried out with the support of the Russian Foundation for Basic Research (projects no. 18-29-12032, no. 20-03-00333) using a facility purchased with funds from the Moscow State University Development Program.

\section{CONFLICT OF INTEREST}

No conflict of interest was declared by the authors.

\section{OPEN ACCESS}

This article is licensed under a Creative Commons Attribution 4.0 International License, which permits use, sharing, adaptation, distribution and reproduction in any medium or format, as long as you give appropriate credit to the original author(s) and the source, provide a link to the Creative Commons license, and indicate if changes were made. The images or other third party material in this article are included in the article's Creative Commons license, unless indicated otherwise in a credit line to the material. If material is not included in the article's Creative Commons license and your intended use is not permitted by statutory regulation or exceeds the permitted use, you will need to obtain permission directly from the copyright holder. To view a copy of this license, visit http://creativecommons.org/licenses/by/4.0/.

\section{REFERENCES}

1. Vashman, A.A., Demin, A.V., Krylova, N.V., Kushnikov, V.V., Matyunin, Yu.I., Poluektov, P.P., Polyakov, A.S., and Teterin, E.G., Fosfatnye stekla s radioaktivnymi otkhodami (Phosphate Glasses with Radioactive Waste), Moscow: TsNIIatominform, 1997.

2. Radioactive Waste Forms for the Future, Lutze, W. and Ewing, R.C., Eds., Amsterdam: Elsevier, 1988.

3. Laverov, N.P., Velichkin, V.I., Omel'yanenko, B.I., Yudintsev, S.V., Petrov, V.A., and Bychkov, A.V., Izolyatsiya otrabotavshikh yadernykh materialov: geologo-geokhimicheskie osnovy (Isolation of Spent Nuclear Materials: Geological and Geochemical Basics), Moscow: IFZ RAN, 2008.

4. Donald, I.W., Waste Immobilization in Glass and Ceramic- 
based Hosts: Radioactive, Toxic, and Hazardous Wastes, UK: Wiley, 2010.

5. Handbook of Advanced Radioactive Waste Conditioning Technologies: Woodhead Publishing Ser. in Energy, no. 12, Ojovan, M.I., Ed., Cambridge: Woodhead, 2011.

6. Vlasova, N.V., Remizov, M.B., Kozlov, P.V., and Belanova, E.A., Vopr. Radiats. Bezopasnosti, 2017, no. 3, pp. 32-37.

7. Malkovsky, V.I., Yudintsev, S.V., and Aleksandrova, E.V., J. Nucl. Mater., 2018, vol. 508, pp. 212-218.

8. Ringwood, A.E., Mineral. Magaz., 1985, vol. 49, pp. 159-176.

9. Lumpkin, G.R., Experimental and Theoretical Approaches to Actinide Chemistry, Gibson, J.K. and de Jong, W.A., Eds., New York: Wiley, 2018.

10. Stefanovsky, S.V. and Yudintsev, S.V., Russ. Chem. Rev., 2016, vol. 85, pp. 962-994.

11. Laverov, N.P., Yudintsev, S.V., Stefanovskii, S.V., Omel'yanenko, B.I., and Nikonov, B.S., Radiochemistry, 2011, vol. 53, no. 3, pp. 229-243.

12. Nefedov, V.I., Rentgenoelektronnaya spektroskopiya khimicheskikh soedinenii (X-ray Electron Spectroscopy of Chemical Compounds), Moscow: Khimiya, 1984.

13. Teterin, Y.A. and Teterin, A.Y., Russ Chem. Rev., 2004, vol. 73, pp. 541-580.

14. Teterin, Y.A. and Teterin, A.Y., Russ. Chem. Rev., 2002, vol. 71, pp. 347-381.

15. Gresch, R., Muller-Warmuth, W., and Dutz, H., J. NonCryst. Solids, 1979, vol. 34, pp. 127-136.

16. Lam, D.J., Paulikas, A.P., and Veal, B.W., J. Non-Cryst. Solids, 1980, vol. 42, pp. 41-48.

17. Pantano, C.G., Glass Science: Experimental Techniques of Glass Science, Simmons, C.J. and El-Bayoumi, O.H., Eds., Am. Ceram. Soc., 1993.

18. Maslakov, K.I., Teterin Yu.A., Stefanovsky, S.V., Kalmykov, S.N., Teterin A.Yu., Ivanov, K.E., and Danilov, S.S., J. Non-Cryst. Solids, 2018, vol. 482, pp. 23-29.

19. Maslakov, K.I., Teterin, Y.A., Ryzhkov, M.V., Popel, A.J., Teterin A.Yu., Ivanov, K.E., Kalmykov, S.N., Petrov, V.G., Petrov, P.K., and Farnand, I., Phys. Chem. Chem. Phys., 2018, vol. 20, pp. 16167-16175.

20. Maslakov, K.I., Stefanovsky, S.V., Teterin, A.Yu., Teterin, Yu.A., and Marra, J.C., Glass Phys. Chem., 2009, vol. 35, pp. 22-28.

21. Maslakov, K.I., Teterin, A.Yu., Teterin, Yu.A., Ivanov, K.E., Yudintsev, S.V., and Stefanovskii, S.V., Radiochemistry, 2012, vol. 54, pp. 115-121. https://doi.org/10.1134/S1066362212020026
22. Maslakov, K.I., Teterin, Yu.A., Stefanovskaya, O.I., Kalmykov, S.N., Teterin, A.Yu., Ivanov, K.E., Yudintsev, S.V., and Myasoedov, B.F., Radiochemistry, 2020, vol. 62, no. 5, pp. 599-607. https://doi.org/10.1134/S1066362220050069

23. Stefanovsky, S.V., Yudintsev, S.V., Nickolsky, M.S., Stefanovsky, O.I., and Skvortsov, M.V., J. Nucl. Mater., 2020, vol. 529, ID 151958.

24. Shirley, D.A., Phys. Rev. B, 1972, vol. 5, pp. 4709-4714.

25. Sosulnikov, M.I. and Teterin Yu.A., J. Electron Spectrosc. Relat. Phenom., 1992, vol. 59, pp. 111-126.

26. Nemoshkalenko, V.V. and Aleshin, V.G., Elektronnaya spektroskopiya kristallov (Electronic Spectroscopy of Crystals), Kiev: Nauk. Dumka, 1976.

27. Ngo, D., Liu, H., Kaya, H., Chen, Z., and Kim, S.H., J. Am. Ceram. Soc., 2019, vol. 102, pp. 6649-6657.

28. Maslakov, K.I., Teterin Yu.A., Popel, A.J., Teterin A.Yu, Ivanov, K.E., Kalmykov, S.N., Petrov, V.G., Springell, R., Scott, T.B., and Farnan, I., Appl. Surf. Sci., 2018, vol. 448, pp. 154-162.

29. Ilton, E.S., Post, J.E., Heaney, P.J., Ling, F.T., and Kerisit, S.N., Appl. Surf. Sci., 2016, vol. 366, pp. 475485.

30. Yamashita, T. and Hayes, P., Appl. Surf. Sci., 2008, vol. 254, pp. 2441-2449.

31. Trzhaskovskaya, M.B. and Yarzhemsky, V.G., Atom. Data Nucl. Data Tables, 2018, vol. 119, pp. 99-174.

32. Yarzhemsky, V.G., Nefedov, V.I., Trzhaskovskaya, M.B., Band, I.M., and Szargan, R., J. Electron Spectrosc. Relat. Phenom., 2002, vol. 123, no. 1, pp. 1-10.

33. NIST X-ray Photoelectron Spectroscopy Database. Version 4.1, Gaithersburg: National Inst. of Standards and Technology, 2012.

34. Ngo, D., Liu, H., Chen, Z., Kaya, H., Zimudzi, T.J., Gin, S., Mahadevan, T., Du, J., and Kim, S.H., NPJ Mater. Degrad., 2020, vol. 4, no. 1. https://doi.org/10.1038/s41529-019-0105-2.

35. Finnie, K.S., Zhang, Z., Vance, E.R., and Carter, M.L., J. Nucl. Mater., 2003, vol. 317, pp. 46-53.

36. Aluri, E.R., Bachiu, L.M., Grosvenor, A.P., Forbes, S.H., and Greedan, J.E., Surf. Interface Anal., 2017, vol. 49, pp. 1335-1344.

37. Runde, W., Los Alamos Sci., 2000, no. 26, vol. 2, pp. 392 411.

38. Choppin, G.R., J. Radioanal. Nucl. Chem., 2007, vol. 273, no. 3, pp. 695-703. 